\title{
Pengaruh Volume Pemberian Air terhadap Pertumbuhan Tiga Varietas Tomat (Lycopersicum esculentum Mill)
}

\author{
Effect Watering Volume on Growth Three Varieties of \\ Tomato (Lycopersicum esculentum Mill)
}

\author{
Roffiul Umamil Marzukoh ${ }^{1)}$, Amalia Tetrani Sakya ${ }^{2)}$, Muji Rahayu ${ }^{2)}$
}

\begin{abstract}
Tomato is one of the agriculture commodity that has many benefits. However, the production of tomato in in low land is still low so it needs effort to increase production. Issues that facing in low land cultivation are high temperature and uncertain water availibility. This study aimed to investigate the effect of watering volume on growth of tomato. This research was conducted at the Greenhouse and Laboratory of Plant Fisiology and Biotechnology, Faculty of Agriculture, Sebelas Maret University. Research was conducted from December 2012 to May 2013. This research used completely randomized factorial design with two factors of treatment, namely variety of tomato were Opal, Gondol and Mutiara and watering volume (4,4 I, 3,42 I, 2,34 I, and 1,28 I in each watering). Data were analyzed by analysis variance and continued by Duncan Multiple Range Test level of $5 \%$. The results showed that the higher of watering volume increases the growth of tomato. Plant height, number of branch, leaf area, dry weight of shoot, dry weight of root and the length of root increase with increasing watering volume. The appropriate tomato that can be developed in the various watering is Gondol.
\end{abstract}

Keywords : watering volume, tomato varieties

\section{PENDAHULUAN}

Tomat (Lycopersicum esculentum) merupakan salah satu komoditas pertanian yang sangat bermanfaat bagi tubuh karena mengandung vitamin dan mineral yang diperlukan untuk pemenuhan gizi. Vitamin A untuk mencegah xeroptalmia pada mata dan penyembuhan penyakit buta malam. Vitamin B untuk mencegah dan mengobati beri-beri, radang syaraf, dermatitis, lemah otot dan penyakit lain akibat kekurangan vitamin B. Vitamin C untuk mencegah sariawan, memelihara kesehatan gigi dan gusi serta melindungi dari penyakit lain yang disebabkan oleh kekurangan vitamin C. Besi ( $\mathrm{Fe})$ berguna untuk pembentukan sel darah merah. Kalsium (Ca) untuk pembentukan tulang dan gigi. Selain itu, buah tomat juga mengandung karbohidrat, kalori, protein, lemak dan fosfor (Depkes RI cit. MB-IPB 2010).

Permintaan pasar yang semakin meningkat terhadap produk sayuran dan manfaat yang baik dari sayuran membuat tomat menjadi pilihan utama danmenjadikan tomat sebagai komoditas yang bernilai ekonomi tinggi. Perkiraan kebutuhan tomat nasional pada tahun 2012 sebesar 920,567 ton (DBPST 2011). Berdasarkan data hasil survei produksi tanaman sayuran di Indonesia tahun 2012, produksi tomat di Indonesia pada tahun 2012 mengalami penurunan sebesar $6,35 \%$ dibandingkan produksi tomat tahun 2011. Produksi total tomat pada

\footnotetext{
1) Undergraduated student of Study of Agrotechnology, Faculty of Agriculture Sebelas Maret University in Surakarta.

2) Lecturer of Study of Agrotechnology, Faculty of Agriculture Sebelas Maret University in Surakarta.

Contact Author: sakya_at@yahoo.com
}

tahun 2011 sebesar 945,046 ton sedangkan pada tahun 2012 sebesar 893,463 ton (BPS 2012).

Lestari (2003) mengemukakan bahwa tanaman famili Solanaceae sangat rentan terhadap kekurangan dan kelebihan air selama masa pertumbuhan. Kurangnya ketersediaan air pada fase pertumbuhan dan perkembangan tanaman akan menyebabkan stres (cekaman) pada tanaman. Hal ini dapat menyebabkan produktivitas dan mutu tomat menurun. Oleh karena itu, dalam budidaya tomat perlu diketahui pemberian air yang sesuai untuk memenuhi kebutuhan air tanaman tomat agar dapat meningkatkan pertumbuhan dan produksi buah tomat. Penelitian ini bertujuan untuk mengetahui pengaruh volume pemberian air terhadap pertumbuhan dan hasil buah tomat.

\section{METODE PENELITIAN}

Penelitian dilaksanakan pada bulan Desember 2012 sampai Mei 2013 di Rumah Kaca A dan Laboratorium Fisiologi Tumbuhan dan Bioteknologi Fakultas Pertanian Universitas Sebelas Maret Surakarta. Bahan yang digunakan pada penelitian ini adalah benih tomat varietas Opal, Gondol, dan Mutiara, tanah Alfisol, pupuk kandang, pupuk urea, $\mathrm{TSP}$, pupuk $\mathrm{KCl}$. Alat yang digunakan dalam penelitian antara lain timbangan, timbangan analitik, bak persemaian, penggaris/mistar, gelas ukur, polibag, oven.

Penelitian menggunakan Ranca-ngan Acak Lengkap (RAL) dengan dua faktor perlakuan yang disusun secara faktorial. Faktor pertama adalah varietas tomat (tomat Opal, Gondol, dan Mutiara). Faktor kedua adalah volume pemberian air $(4,4 \mathrm{I}, 3,42$ I, 2,34 I, dan 1,28 I per siraman) sehingga terdapat 12 kombinasi perlakuan dan masing-masing kombinasi diulang 6 kali. Variabel yang diamati yaitu tinggi 
tanaman, jumlah cabang, luas daun, jumlah bunga, berat kering tajuk, berat kering akar, panjang akar Tabel 1. Pengaruh pemberian air dan beberapa varietas tomat terhadap tinggi tanaman pada umur 13 MST (cm)

\begin{tabular}{|c|c|c|c|c|c|}
\hline \multirow{2}{*}{ Varietas } & \multicolumn{4}{|c|}{ Volume pemberian air (liter) } & \multirow{2}{*}{ Rerata } \\
\hline & 4,4 & 3,42 & 2,34 & 1,28 & \\
\hline $\begin{array}{l}\text { Opal } \\
\text { Gondol } \\
\text { Mutiara }\end{array}$ & $\begin{array}{l}158,33^{\mathrm{d}} \\
193,33^{\mathrm{e}} \\
142,83^{\mathrm{cd}}\end{array}$ & $\begin{array}{l}160,67^{d} \\
158^{d} \\
150,67^{c d}\end{array}$ & $\begin{array}{l}138^{\mathrm{bcd}} \\
153^{\mathrm{d}} \\
130^{\mathrm{abcd}}\end{array}$ & $\begin{array}{l}100^{\mathrm{a}} \\
114,67^{\mathrm{abc}} \\
105^{\mathrm{ab}}\end{array}$ & $\begin{array}{l}139,25 \\
154,75 \\
132,125 \\
\end{array}$ \\
\hline Rerata & 164,83 & 156,45 & 140,33 & 106,56 & $(+)$ \\
\hline
\end{tabular}

Keterangan: Nilai yang diikuti huruf yang berbeda dalam satu baris dan satu kolom menunjukkan berbeda nyata pada uj Duncan taraf $5 \%$. (+): Terdapat interaksi.

dan rasio akar tajuk. Data dianalisis menggunakan analisis ragam (Anova) dengan uji $\mathrm{F}$ 5\% dan apabila terdapat beda nyata dilanjutkan uji jarak berganda (DMRT) taraf $5 \%$.

\section{HASIL DAN PEMBAHASAN}

\section{Tinggi Tanaman}

Tinggi tanaman merupakan indikator pertumbuhan yang sering diamati. Hal ini didasarkan bahwa tinggi tanaman merupakan ukuran pertumbuhan yang mudah dilihat (Sitompul dan Guritno 1995). Hasil analisis ragam menunjukkan bahwa terdapat interaksi antara volume pemberian air dan varietas tomat terhadap tinggi tanaman tomat

Ketersediaan air dalam jumlah yang cukup merupakan hal penting bagi produksi pertanian. Tabel 1 menunjukkan tomat varietas Gondol dengan penyiraman 4,4 I menghasilkan purata tinggi tanaman tertinggi dan berbeda nyata dengan perlakuan lainnya. Ketersediaan air 1,28 I pada ketiga varietas menghasilkan tinggi tanaman terendah. Hal ini selaras dengan Wahb-Allah et al. (2011), menyatakan bahwa volume pemberian air yang sedikit akan menyebabkan penurunan tinggi tanaman. Menurut Pervez et al. (2009), tanaman yang tidak tercekam menghasilkan tinggi tanaman yang paling tinggi dibandingkan yang tercekam.

Pertumbuhan tinggi tanaman dipengaruhi oleh kadar lengas tanah. Hal itu dikarenakan proses tinggi tanaman yang diawali dengan proses pembentukan tunas merupakan proses pembelahan dan pembesaran sel. Kedua proses ini dipengaruhi oleh turgor sel. Proses pembelahan dan pembesaran sel akan terjadi apabila sel mengalami turgiditas yang unsur utamanya adalah ketersediaan air (Samanhudi 2010). Adanya penurunan turgiditas dapat menghentikan perbesaran sel dan mengakibatkan pengkerdilan tanaman (Kramer 1969).

\section{Jumlah Cabang}

Jumlah cabang merupakan variabel penting dalam penelitian, sebab pada cabang akan muncul bunga sehingga apabila cabang yang terbentuk cukup banyak maka hasil akan berbanding lurus. Hasil analisis ragam menunjukkan tidak terdapat interaksi antara volume pemberian air dan varietas tomat terhadap jumlah cabang. Perlakuan pemberian air berpengaruh nyata terhadap jumlah cabang sedangkan varietas tomat tidak berpengaruh nyata terhadap jumlah cabang.
Tabel 2. Pengaruh volume pemberian air dan varietas tomat terhadap jumlah cabang tanaman pada umur 13 MST

\begin{tabular}{cc}
\hline $\begin{array}{c}\text { Volume pemberiaan air } \\
\text { (liter) }\end{array}$ & Jumlah cabang \\
\hline 1,28 & $2,11^{\mathrm{a}}$ \\
2,34 & $2,78^{\mathrm{b}}$ \\
3,42 & $3,56^{\mathrm{c}}$ \\
4,4 & $4,11^{\mathrm{c}}$ \\
\hline
\end{tabular}

Keterangan: Nilai yang diikuti huruf yang berbeda dalam satu kolom menunjukkan berbeda nyata pada uji Duncan taraf $5 \%$.

Tabel 2 menunjukkan bahwa purata jumlah cabangtertinggi pada volume pemberian air 4,4 I (4,11 cabang). Tanaman yang mengalami cekaman air akan terganggu metabolisme dan pertumbuhannya yang menyebabkan penurunan jumlah cabang. Nawangsih cit. Hartati (2000) menyebutkan bahwa tanpa adanya aliran fotosintat yang memadai akan menghambat pertumbuhan dan perkembangan tanaman menjadi dewasa, sehingga dengan kurang tersedianya air jumlah cabang tanaman tomat akan menjadi sedikit.

\section{Luas Daun}

Daun merupakan organ utama tanaman yang menyerap radiasi matahari. Hasil berat kering total merupakan hasil efiensi penyerapan dan pemanfaatan radiasi matahari yang tersedian selama pertumbuhan oleh tajuk tanaman (Goldsworthy dan Fisher 1996). Hasil analisis ragam menunjukkan bahwa terdapat interaksi antara volume pemberian air dan varietas tomat terhadap luas daun.

Tabel 3 menunjukkan bahwa tomat varietas Gondol dengan volume pemberian air 4,4 । menghasilkan purata luas daun tanaman yang tertinggi $\left(241,15 \mathrm{~cm}^{2}\right)$ dan berbeda nyata dengan perlakuan lainnya. Varietas Gondol memiliki ukuran daun lebih lebar sehingga dengan penyiraman cukup daun tanaman akan berkembang dengan maksimal. Menurut Sakya dan Rahayu (2010), tanaman dengan permukaandaun yang luas akan mengakibatkan faktor-faktor yang dibutuhkan tanaman untuk fotosintesis akan mudah terpenuhi sehingga proses fotosintesis akan dapat berjalan dengan lebih maksimal. Luas daun tanaman semakin mengecil seiring dengan pertambahan cekaman air. Ukuran luas daun yang mengecil merupakan mekanisme penghindaran tanaman menekan kehilangan air untuk 
mengurangi terjadinya transpirasi pada tanaman (Khaerana 2007).

\section{Berat Kering Tajuk, Berat Kering Akar, dan Panjang Akar}

Berat kering tumbuhan yang berupa biomassa total, sebagai manifestasi proses metabolisme yang terjadi di dalam tubuh tumbuhan. Berat kering menunjukkan produktivitas tanaman karena $90 \%$ foto sintesintat terdapat dalam bentuk berat kering (Gardner et al. 1991).

Hasil analisis ragam menunjukkan bahwa tidak terdapat interaksi antara volume pemberian air dan varietas tomat terhadap berat kering tajuk, berat kering akar, dan panjang akar tanaman tomat. Perlakuan volume pemberian air berpengaruh nyata terhadap berat kering tajuk, berat kering akar, dan panjang akar, sedangkan varietas tomat tidak berpengaruh nyata terhadap berat kering tajuk, berat kering akar, dan panjang akar tanaman tomat.
Tabel 4. menunjukkan bahwa berat kering tajuk tertinggi pada volume pemberian air 4,4 I (61,7 gram) dan berbeda nyata dengan perlakuan lainnya. Berat kering tajuk terendah pada volume pemberian air 1,28 I disebabkan oleh laju fotosintesis yang rendah akibat kekurangan air. Menurut Zgallai et al. (2006), perlakuan cekaman air pada taraf sedang sampai tinggi menghambat laju fotosintesis tanaman tomat.

Volume pemberian air 4,4 L menghasilkan purata berat kering akar tertinggi (3,06 gram), meskipun tidak beda nyata dengan volume pemberian air 3,42 I.Cekaman air akan menyebabkan transport unsur hara dalam tanaman terganggu yang berakibat pada proses biokimia (Nonami dan Boyer 1997), hal ini dicerminkan bobot kering tanaman rendah. Nahar dan Gretzmacher (2002), menyatakan bahwa pengaruh interaksi antara kekurangan air dengan kultivar tomat sangat signifikan terhadap hasil berat kering tanaman, kebanyakan kultivar kekurangan air menghasilkan berat kering yang lebih rendah.

Tabel 3. Pengaruh volume pemberian air dan varietas tomat terhadap luas daun pada umur $13 \mathrm{MST}\left(\mathrm{cm}^{2}\right)$

\begin{tabular}{llllll}
\hline \multirow{2}{*}{ Varietas } & \multicolumn{5}{c}{ Volume Pemberian Air (liter) } \\
\cline { 2 - 5 } & \multicolumn{1}{c}{4,4} & 3,42 & \multicolumn{1}{c}{ Rerata } \\
\hline Opal & $106,99 \mathrm{cde}$ & $104,44 \mathrm{cde}$ & $62,15 \mathrm{abc}$ & $57,04 \mathrm{abc}$ & 82,66 \\
Gondol & $241,15 \mathrm{f}$ & $147,65 \mathrm{e}$ & $101,03 \mathrm{cde}$ & $39,85 \mathrm{ab}$ & 132,42 \\
Mutiara & $104,58 \mathrm{cde}$ & $121,47 \mathrm{de}$ & $80,03 \mathrm{bcd}$ & $24,83 \mathrm{a}$ & 82,73 \\
Rerata & 150,9067 & 124,52 & 81,07 & 40,57 & $(+)$
\end{tabular}

Keterangan: Nilai yang diikuti huruf yang berbeda dalam satu baris dan satu kolom menunjukkan berbeda nyata pada uji Duncan taraf $5 \%$. (+): Terdapat interaksi.

Tabel 4. Pengaruh volume pemberian air dan varietas tomat terhadap berat kering (tajuk dan akar) dan panjang akar tanaman pada umur 13 MST

\begin{tabular}{cccc}
\hline $\begin{array}{c}\text { Volume Pemberian Air } \\
\text { (liter) }\end{array}$ & $\begin{array}{r}\text { Berat Kering Tajuk } \\
(\text { gram) }\end{array}$ & $\begin{array}{c}\text { Berat Kering Akar } \\
(\text { gram) }\end{array}$ & Panjang Akar $(\mathrm{cm})$ \\
\hline 1,28 & $13,76^{\mathrm{a}}$ & $1,33^{\mathrm{a}}$ & $33,78^{\mathrm{a}}$ \\
2,34 & $32,22^{\mathrm{b}}$ & $2,06^{\mathrm{b}}$ & $50,41^{\mathrm{b}}$ \\
3,42 & $48,94^{\mathrm{C}}$ & $2,88^{\mathrm{c}}$ & $51,37^{\mathrm{b}}$ \\
4,4 & $61,70^{\mathrm{d}}$ & $3,06^{\mathrm{c}}$ & $54,81^{\mathrm{b}}$ \\
\hline
\end{tabular}

Keterangan: Nilai yang diikuti huruf yang berbeda dalam satu kolom menunjukkan berbeda nyata pada uji Duncan taraf $5 \%$.

Menurut Palupi dan Yopy (2008), panjang akar berkaitan dengan ketahanan tanaman pada saat tercekam kekeringan. Tabel 4 menunjukkan bahwa purata panjang akar tertinggi pada volume pemberian air 4,4 । $(54,81 \mathrm{~cm})$. Volume pemberian air 1,28 । menghasilkan purata panjang akar terendah $(33,78$ $\mathrm{cm})$ dan berbeda nyata dengan perlakuan lainnya.

Penghambatan perkembangan akar, selain disebabkan oleh terhambatnya aktivitas sel juga disebabkan oleh daerah penetrasi akar dalam keadaan kering (kelembaban tanah rendah) sehingga akar yang baru terbentuk tidak dapat menembusnya dan akhirnya ujung akar mati. Menurut Islami dan Utomo (1995), salah satu bentuk terhambatnya pembentukan dan perkembangan sel akibat cekaman air adalah terbentuknya akar tanaman yang sedikit, ukuran kecil, dan daerah penyebaran yang relatif sempit.

\section{Rasio Akar Tajuk}

Rasio akar tajuk digunakan untuk mengetahui kemampuan tanaman dalam mempertahankan keseimbangan fungsional di lingkungan yang mengalami cekaman. Pertumbuhan tajuk lebih digalakkan apabila tersedia $\mathrm{N}$ dan air yang banyak, pertumbuhan akar lebih digalakkan apabila faktor $\mathrm{N}$ dan air terbatas (Solichatun et al. 2005). Hasil analisis ragam menunjukkan bahwa tidak terjadi interaksi antara volume pemberian air dan varietas tomat terhadap rasio akar tajuk tanaman tomat

Tabel 5 menunjukkan tidak terjadi interaksi antara volume pemberian air dan varietas tomat terhadap rasio akar tajuk tanaman tomat. Menurut Irianto et al. (2011), rasio akar tajuk pada dasarnya mencerminkan besaran alokasi fotosintat antara akar dengan tajuk, umumnya efek cekaman air dan zat penghambat tumbuh mendorong alokasi fotosintat yang lebih banyak ke akar sehingga akar berkembang dan rasio akar tajuk meningkat. Akan tetapi, dalam penelitian volume pemberian air dan varietas tomat tidak 
berpengaruh nyata terhadap rasio akar tajuk tanaman tomat.

Tabel 5. Pengaruh volume pemberian air dan varietas tomat terhadap rasio akar tajuk pada umur 13 MST (\%)

\begin{tabular}{|c|c|c|c|c|c|}
\hline \multirow[b]{2}{*}{ Varietas } & \multicolumn{4}{|c|}{ Volume Pemberiaan Air (liter) } & \multirow[b]{2}{*}{ Rerata } \\
\hline & 4,4 & 3,42 & 2,34 & 1,28 & \\
\hline Opal & 0,15 & 0,19 & 0,12 & 0,11 & $0,15^{\mathrm{a}}$ \\
\hline Gondol & 0,11 & 0,19 & 0,21 & 0,29 & $0,2^{\mathrm{a}}$ \\
\hline Mutiara & 0,27 & 0,17 & 0,08 & 0,10 & $0,16^{\mathrm{a}}$ \\
\hline Rerata & $0,18^{\mathrm{a}}$ & $0,18^{\mathrm{a}}$ & $0,14^{\mathrm{a}}$ & $0,17^{\mathrm{a}}$ & $(-)$ \\
\hline
\end{tabular}

Keterangan: Nilai yang diikuti huruf yang sama dalam satu baris dan satu kolom menunjukkan tidak berbeda nyata pada uj Duncan taraf $5 \%$. (-): Tidak terdapat interaksi.

Akar-akar tanaman tumbuh ke arah air tanah. Penanaman tanaman tomat di dalam polibag sehingga ruang tumbuh akar terbatas yang menyebabkan rhizosfer (daerah pertumbuhan akar) terbatas sehingga pertumbuhan dan perkembangan akar terbatas. Selain itu, volume tanah terbatas sehingga volume air yang tersedia untuk pertumbuhan tanaman terbatas menyebabkan pertumbuhan akar tidak optimal. Menurut Islami dan Utomo (1995), jumlah air dan hara yang diabsorbsi oleh tanaman ditentukan oleh volume tanah yang bersentuhan dengan akar.

\section{KESIMPULAN DAN SARAN}

\section{Kesimpulan}

Berdasarkan penelitian yang telah dilakukan maka dapat diambil kesimpulan sebagai berikut :

1. Tinggi tanaman, jumlah cabang, luas daun, berat kering tajuk, berat kering akar, dan panjang akar meningkat seiring meningkatnya volume pemberian air $(4,4 \mathrm{I})$.

2. Varietas tomat yang sesuai dikembangkan pada berbagai volume pemberian air adalah varietas Gondol.

\section{Saran}

Saran yang diberikan dalam penelitian ini sebagai berikut :

1. Penyiraman tanaman tomat dengan volume pemberian air 4,4 I diperlukan untuk mendapatkan pertumbuhan yang baik.

2. Perlu dilakukan penelitian lebih lanjut mengenai cekaman air dengan menggunakan varietas tomat yang lainnya.

\section{DAFTAR PUSTAKA}

Badan Pusat Statistik [BPS)]. 2012. Produksi tomat menurut Provinsi. Badan Pusat Statistik dan direktoral Jendral Hortikultura. Jakarta.

Direktorat Budidaya dan Pasca Panen Sayuran dan Tanaman Obat [DBPST]. 2011. Koordinasi penetapan pola produksi. http://ditsayur. hortikultura.deptan.go.id. Diakses 6 November 2013.

seed quality of tomato (Lycopersicon esculuntum L). Pak. J Agri Sci 46(3): 174-178.

Sakya AT, Rahayu M. 2010. Pengaruh pemberian unsur mikro besi $(\mathrm{Fe})$ terhadap kualitas anthurium. Agrosains 12(1): 29-33.
Goldsworthy PR, Fisher NM. 1996. Fisiologi tanaman budidaya tropik. Yogyakarta (ID): Gadjah Mada University Press.

Gardner FP, Pearce RB, Roger LM. 1991. Fisiologi tanaman budidaya. Jakarta (ID): UI Press.

Hartati S. 2000. Penampilan genotip tanaman tomat (Lycopersicum esculentum mill.) hasil mutasi buatan pada kondis stress air dan kondisi optimal. Agric Sci 2(2): 35-42.

Islami T, Utomo WU. 1995. Hubungan tanah, air dan tanaman. Semarang (ID): IKIP Press.

Irianto, Budiyati I, Mapegau. 2011. Pengaruh zat penghambat tumbuh cycocel dalam meningkatkan toleransi bibit manggis pada berbagai tingkat cekaman air. J Agriv 10(3): 300-308.

Khaerana. 2007. Pengaruh cekaman kekeringan dan umur panen terhadap pertumbuhan dan kandungan xanthorrizol tanaman temulawak (Curcuma xanthorrhiza Roxb). Tesis. Program Studi Agronomi Institut Pertanian Bogor.

Kramer. 1969. Plant and soil water relationship, a modem synthesis. New York (NY): Mc GrawHill Co. Ltd.

Lestari E. 2003. Simulasi potensi hasil dan pengaruh cekaman air pada tanaman kentang (Solanum tuberosum I.) di kecamatan Lembang kabupaten Bandung. Skripsi. Institut Pertanian Bogor.

MB-IPB. 2010. Export tomat. Program Pasca Sarjana Manajemen dan Bisnis Institut Pertanian Bogor.

Nahar, Gretzmacher. 2002. Effect of water stress on nutrien uptake, yield and quality of tomato (Lycopersicon esculentum Mill.) under subtropical conditions. Die Bodenkultur 53(1): 45-51.

Nonami HY, Utomo Wu, Boyer JS. 1997. Decreased growth induced water potential. Plant Physiol 114: 501- 509.

Palupi ER, Yopi D. 2008. Kajian karakter ketahanan terhadap cekaman kekeringan pada beberapa genotif kelapa sawit (Elaes guineensis Jocq). Bul Agron 36(1): 24-32.

Pervez MA, Ayub CM, Khan HA, Shahid MA, Ashraf I. 2009. Effect of drought stress on growth, yield and

Samanhudi. 2010. Pengujian cepat ketahanan tanaman sorgum manis terhadap cekaman kekeringan. Agrosains 12(1): 9-13.

Sitompul SM, Guritno B. 1995. Analisis pertumbuhan tanaman. Yogyakarta (ID): Gadjah Mada University Press. 
Solichatun, Endang A, Widya M. 2005. Pengaruh ketersediaan air terhadap pertumbuhan dan kandungan bahan aktif saponin tanaman Ginseng Jawa (Talinum paniculatum Gaertn.). Biofarmasi 3 (2): $47-51$.

Wahb-Allah MA, Alsadon AA, Ibrahim AA. 2011. Drought tolerance of several tomato genotype under greenhouse condition. World Appl Sci J 15(7): 933-940.

Zgallai H, Steppe K, Lemeur R. 2006. Effect of different level of water stress on leaf water potensial, stomatal resistance, protein and chlorophyll content and certain anti-oxidative enzymes in tomat plants. J Int Plan Biol 48(6): 679687. 